\title{
Lasting Lessons in Outdoor Learning: A Facilitation Model Emerging from 30 Years of Reflective Practice
}

\author{
Tonia Gray ${ }^{1}$ and Fiona Pigott ${ }^{2}$ \\ ${ }^{7}$ Western Sydney University School of Education, Penrith, \\ Australia. \\ ${ }^{2}$ New South Wales Department of Education-Learning \\ and Support, Nowra, Australia.
}

\section{Abstract}

Engaging with nature is needed for the holistic development of children. However, a lack of longitudinal research exists to outline the impact of Outdoor Learning in the school curriculum. In our current educational climate which places inordinate focus upon evidencebased outcomes, teachers are needing encouragement to embrace unconventional nature-based pedagogies. In the late 1970s, a bespoke Wilderness Studies class was introduced in an Australian school for adolescents which extended over two full academic years. Three decades later, these students were contacted to assess the residual impact of this pioneering teaching method. Utilizing social media research techniques, the study unveils their salient memories to enable a better understanding of the enduring impact of nature immersion. Invariably, respondents argued the outdoor experiences eclipsed their indoor classroom counterpart and left an indelible impression on their formative years of education. Surprisingly, a large number had occupations involving outdoor leadership or environmental stewardship. Our retrospective study conveys the $d u$ rability of Outdoor Learning 30 years after completion. We conclude with a facilitation model underpinned by three Rs: Resilience, Reflection, and Relationship emanating from reflecting on years of successful pedagogical practice. Derived from positive psychology, contemplative practice, storytelling, indigenous teachings, and slow pedagogies, the core elements have been incorporated into a learning framework. Lessons learned from the trailblazing pedagogy have helped distil the key principles needed in the 21 st-century curriculum. As we head toward a new era of nature-estranged students, these findings offer insights and gravitas for educators searching for tangible pathways to engage students with wild spaces. Key Words: Retrospective study-Outdoor learning-AdolescenceNature immersion-School curriculum-Wilderness studies.

\section{The Backstory: Planting and Tending the Idea}

hirty-five years ago, in the early 1980s, one of the authors of this paper stumbled across the field of Outdoor Learning purely by accident. At the time, an innovative Australian school was implementing a 2-year nature-immersive curriculum for 14- to 15-year-old high school students called Wilderness Studies (see Fig. 1). Developed and first implemented in the late 1970s, Wilderness Studies was primarily conceived as a novel curriculum experiment.

Blazing the trail together, the teaching staff became the pioneers and the students the unsuspecting guinea pigs (Gray, 2017; Gray \&t Perusco, 1993; Ryan \& Gray, 1993). In this vanguard learning movement, they were metaphorically "salmon swimming upstream" in an overly boring and rigid educational system. Conventional classroom teachers dismissed the subject as simply whimsical and a waste of time "playing" in nature. However, teaching in partnership with the natural world provided a compelling platform for transformational learning (Gray, 2018b; Mezirow, 2000).

As an elective course, students spent as much time in the "wild" as they did in other conventional subjects, such as mathematics or English. For two consecutive school years (Year 9 and 10), a significant amount of time was spent outdoors with these 14- to 15 -year-old students ( $n=25$; 8 females and 17 males), in a state-ofthe-art curriculum. 


\section{GRAY AND PIGOTT}

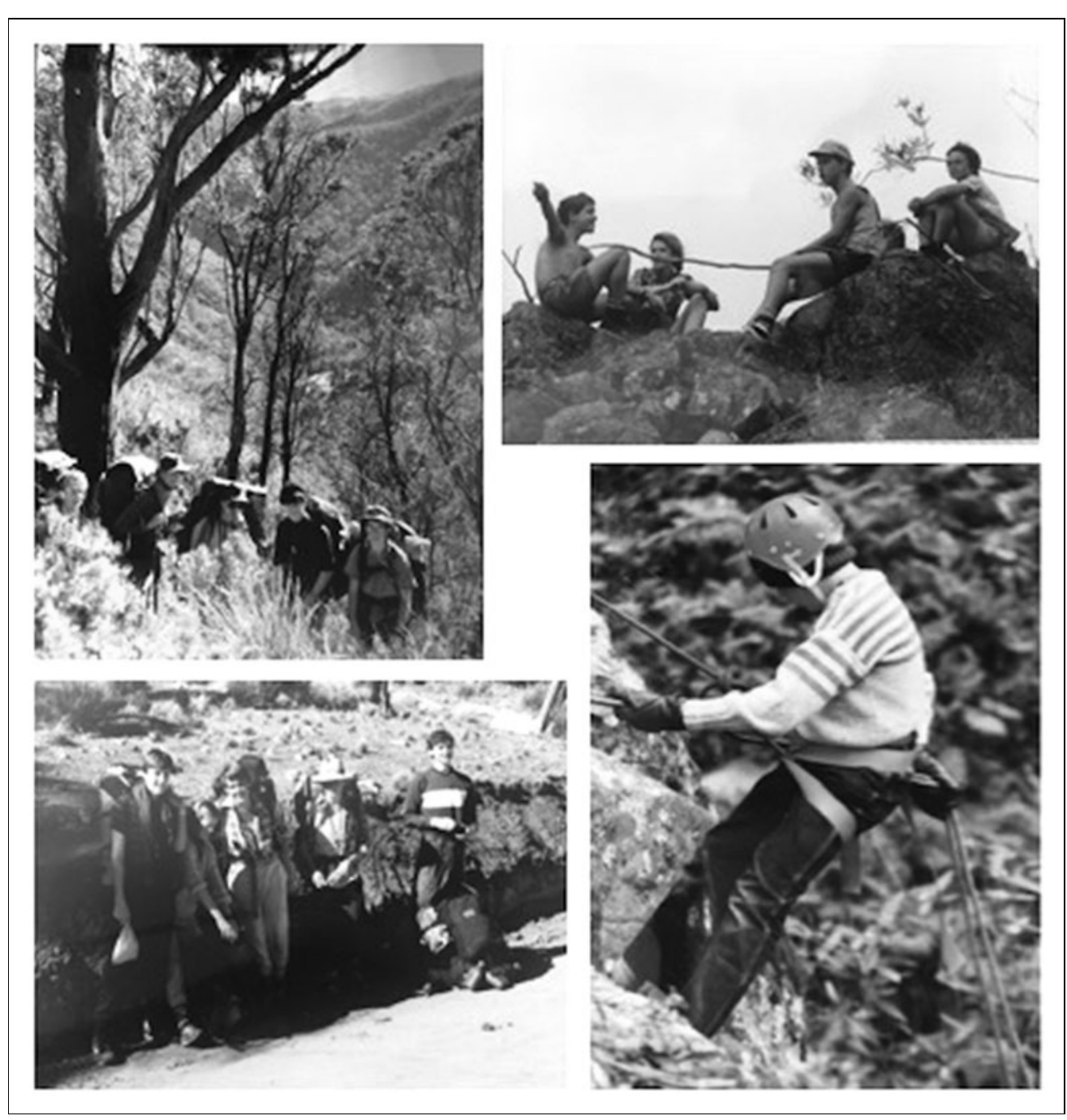

Fig. 1. Pictures of the Wilderness Studies students, 1985-1986. (Photo credit: Tonia Gray) comitantly, the logbooks were incorporated into the classroom setting for self-analysis and goal-setting.

A poignant poem written by a 14year-old student in her logbook in 1985 (see Fig. 3) showcases aspects of the learning outcomes that were elicited during these simple, and sometimes unscripted, introspective exercises.

\section{Data Collection Methods: Investigating the Long-Term Harvest}

Significant literature exists to reveal that Outdoor Learning generates autobiographical episodic memories (Barton, Bragg, Pretty, Roberts, \& Wood, 2016; Chawla, 2007; Dickson, Gray, \&t Mann, 2008; Gray, 2018a; Hattie, Marsh, Neill \&t Richards, 1997; Liddicoat \& Krasny, 2014; Sibthorp, Paisley, Furman, \&t Gookin, 2008). In 2016, based on this proposition, we revisited the 1985-1986 adolescent participants, now 45-46 years of age, to explore the residual impact of Outdoor Learning during their adolescent years. We traced their life journeys into adulthood in an attempt to map the enduring or longitudinal effect. In particular, we examined how these immersive nature-based experiences shaped their behavior, attitudes, skills, values, and, ultimately, professional choices.

Along with physical challenges and time spent exploring nature, opportunities were provided for introspection, contemplative solo time, and silent journaling in their logbooks. These were embedded into the course assessment tasks using Kolb's (1984) experiential learning cycle as a schematic framework. Journals were carried in their backpacks to allow for reflective activities whilst on expedition. Outdoor rituals were orchestrated-either around the campfire or during lunchtime rest periods-where contemplative writing sessions or nature-based creative arts activities occurred (see Fig. 2). Con-
Ethics approval was granted by Western Sydney University for the use of social media to augment the process of locating past participants. A mixed-methods research design sought both qualitative and quantitative measures. The study was able to contact more than half of the original 25 students; regrettably, one had passed. Quantitative data was gathered using an online survey tool where the Qualtrics link was sent through Facebook Messenger. For readers requiring deeper insights into this research method, the initial findings are elaborated upon in Gray (2017). Eleven responded to our request to 


\section{LASTING LESSONS IN OUTDOOR LEARNING}
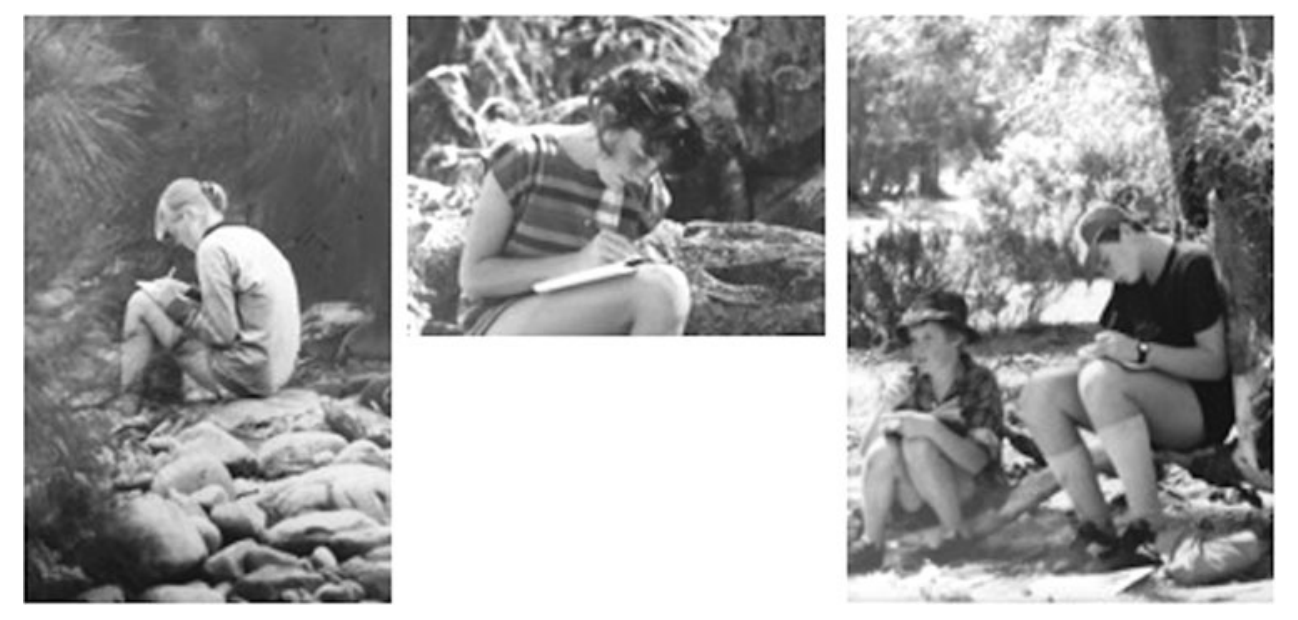

4. If you were 15 years of age, would you do it all again? What advice would you give to your 15-year-old self?

5. Do you believe the Wilderness Studies course helped shaped your career development, career choices, etc. at all?

\section{Key Findings-Bearing Fruit with a Sustained Harvest}

The focus of this paper is to apply these lessons to today's educational context, looking through the lens of reflexive contemporary practition-

Fig. 2. Pictures of students in 1985-1986 undertaking silent journaling. (Photo credit: Tonia Gray)

ers. We proffer that the innovative,

participate, ensuring a 46\% response rate. Qualitative data was obtained through in-depth interviews with a subset of four participants.

We specifically investigated the lasting lessons of Outdoor Learning in relation to five key Research Questions.

1. What three words would sum up your Wilderness Studies experience?

2. What were the benefits of Wilderness Studies for you personally, socially, physically, emotionally or spiritually?

3. Wilderness Studies required you to participate in some demanding hikes as 15- to 16-year-olds-what were the hardships you remember? Do you have any regrets about participating in the program?

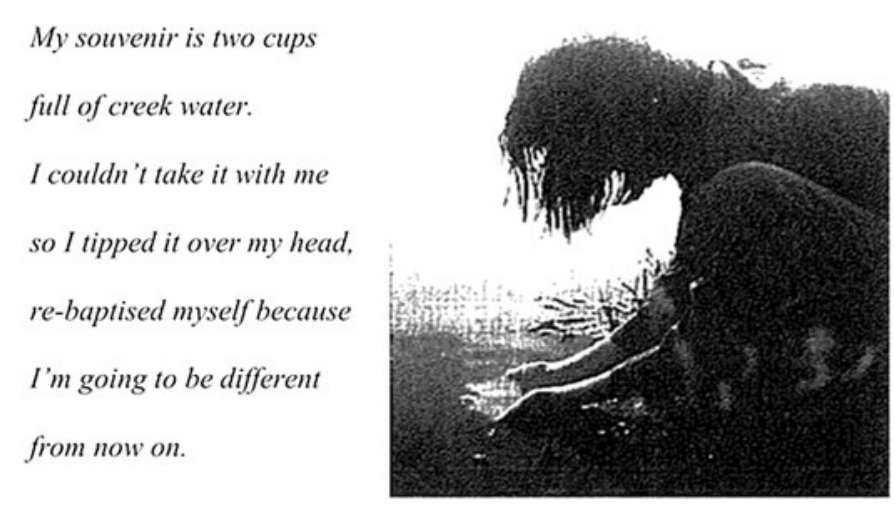

Fig. 3. Student cupping water over her re-baptised self. (Photo credit: Des Ryan) intuitive action taken three decades ago to augment students' connection with nature can now be validated by current research to advance our field to a new level of maturity. From humble beginnings in an unverified and somewhat controversial program, unequivocal pedagogical links can now be drawn with place-based immersion, embodied learning, positive psychology, and neuroplasticity. Along with being directly applicable to today's learners, contemporary teachers may be encouraged to take their own innovative, intuitive actions and, in doing so, contribute to the evolution of educational practice.

From a longitudinal perspective, amassing a substantive pool of evidence-based longitudinal research in Outdoor Learning can be somewhat problematic. And yet, for this small cohort $(n+9)$ the gravity of the nature-based experience was unquestionable. To this end, being grounded ontologically was the primary goal of the 30year retrospective study. The research poses questions about how far we have come as educational practitioners in both theory and practice. However, we caution that the retrospective nature of this study cannot specifically pinpoint whether the experience of Outdoor Learning was the solitary reason for attitudinal and behavioral change. More importantly, our reflections on their Wilderness Studies experience may have acted as a conduit to reflect on life lessons more generally. Nonetheless, the salient findings signal that Wilderness Studies provided

- an opportunity for friendship, peace, and conservation;

- a rewarding experience, despite hardship, they would recommend to today's youth; 


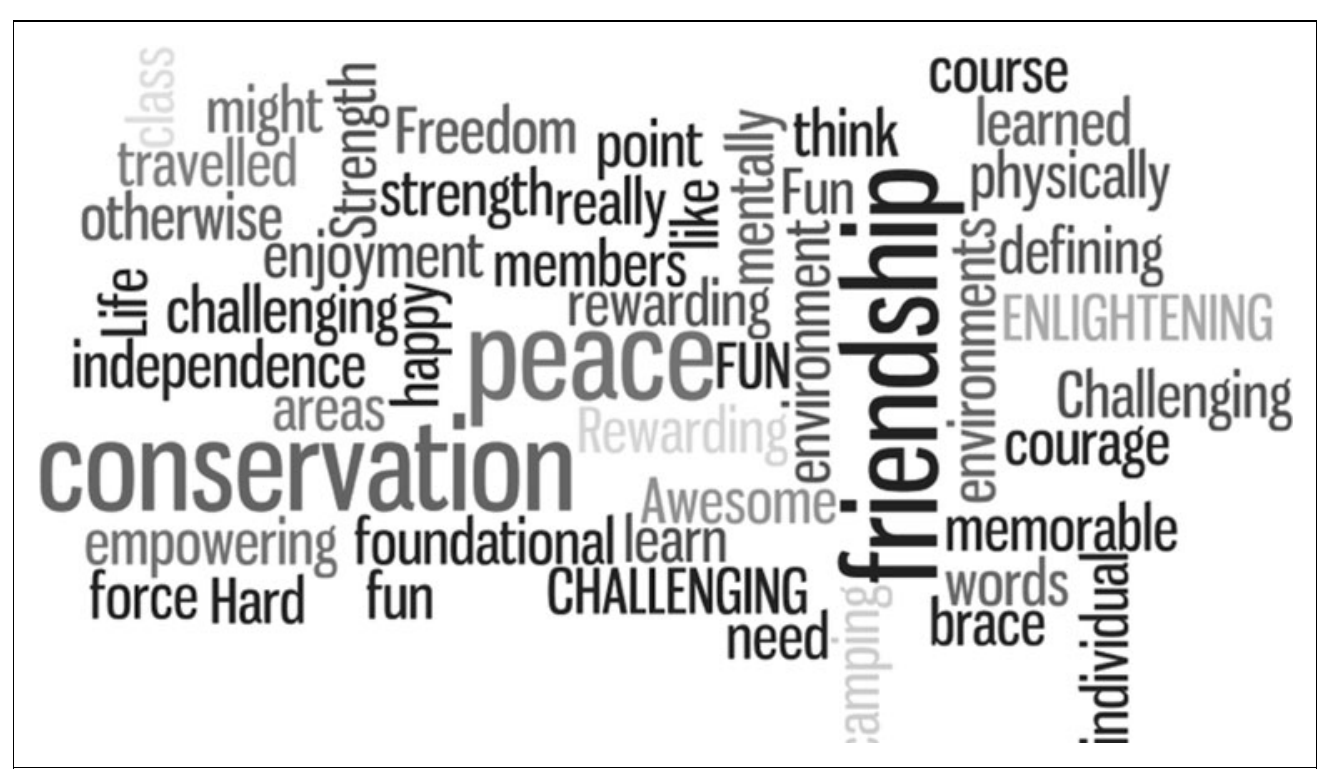

Fig. 4. Wordle summing up Wilderness Studies experiences.

- a precious tangible memory that was carefully kept in log books and printed photos; and

- a motivating factor in their current careers, recreational choices, and attunement with nature.

The Wordle (Fig. 4) was derived from the top three words used to describe participants' experience. The size of the font indicates words most commonly featured in the online survey.

Friendship is identified as a key recollection of the experience, which does not seem surprising given adolescents' preoccupation with, and the value they place on, social connection (Buhrmester, 1990; Bukowski, Hoza, Ct Boivin, 1993). The opportunity to travel, be physically challenged, and experience strength, courage, freedom, and membership with their peers in Wilderness Studies has added to the layers of shared experiences. Collectively, these forms of experiential learning help galvanize the friendships so important to navigating the challenges of adolescent life.

Participants alluded to the cathartic and restorative elements of nature immersion when using the words peace, enlightening, enjoyment, fun, rewarding. Hoogerheide and Paas (2012) suggest that pleasant learning experiences increase intrinsic motivation, resulting in better academic outcomes. The frequent use of the terms "learn, course, class" indicates participants understand Wilderness Studies was an educational provision, with conservation of the environment as a significant application of their learning.
Many indicated they would do it all again in a heartbeat and highly recommended the experience to adolescents today. Emotions played an integral role in embedding learning and assisting recall. The hardship and adversity encountered were at the forefront of their memories yet were ultimately recollected as positives. This "remembered utility" is the propensity for the peak or end experience to influence our evaluation of an experience as worthwhile, even if it was at times, unpleasurable (Kahneman \&t Tversky, 2000, as cited in Hoogerheide \& Paas, 2012). That is, whilst Wilderness Studies was physically and emotionally demanding at times, the overall experience is associated with positive emotions. Unquestionably, all respondents insisted that they increased their tenacity and resilience as a direct outcome of the outdoor education experience.

These three quotes give a snapshot of some of the participant responses received to Research Question 4: If you were 15 years of age, would you do it all again? What advice would you give to your 15year-old self?

Embrace your misfit self because it will be a better life than in the beige desperation of the suburbs.

The most important journey in your life will be to find your tribe. You will meet some inspiring and amazing people but you must put yourself out there to meet them.

A life lived in fear is a life half lived.

Educational psychologist Steve Biddulph (2013) suggests the job of the adolescent is to "find their soul" (p. 89), or that misfit part of themselves that makes them wonderfully different from others. In other words, that which guides them into adventure and away from the beige desperation of a monotonous life. More specifically, the job of the significant adults in their life is to surround them with a tribe of inspiring and amazing young people and warm-hearted elders. Providing adolescents time in wild and beautiful places enables momentary disorientation as they experience themselves not as isolated individuals but as belonging to an interconnected web of life (Biddulph, 2013). Here, the participants give similar advice to their 


\section{LASTING LESSONS IN OUTDOOR LEARNING}

younger selves, acknowledging the struggle to embrace the awkward self is hard but suggesting that living with fear or in a soulless drudgery is worse.

Many had pursued careers involving conservation, wilderness guiding, or environmental education. Interestingly, the majority had also kept tangible items such as their Wilderness Studies logbooks and printed photos. Kept in special boxes and sacred spaces, these treasured memories were retained for over three decades by nearly half the participants. One who now manages his own

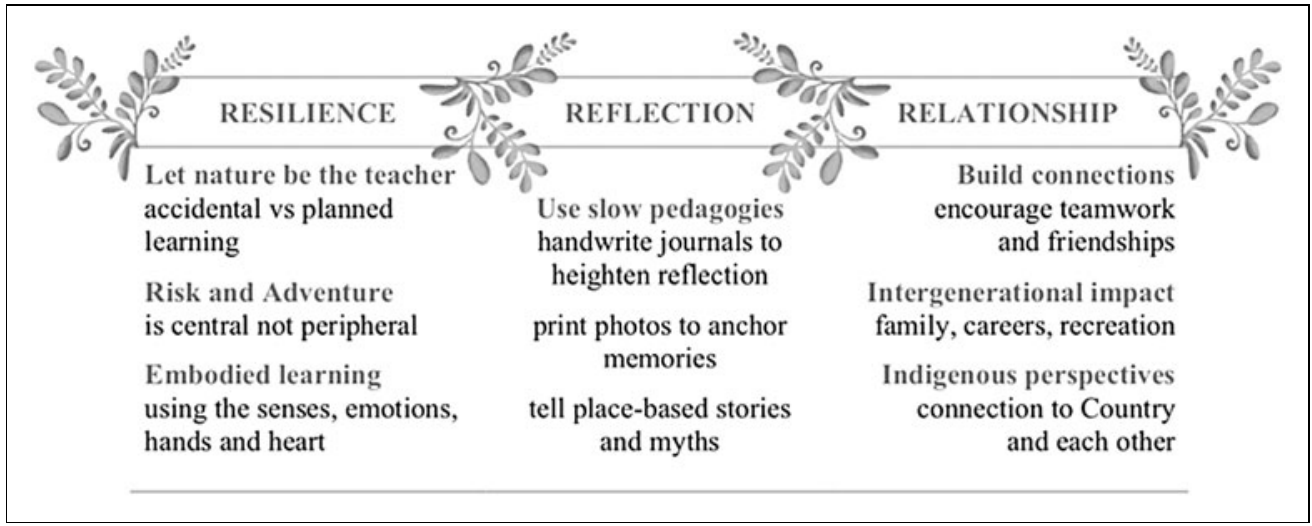

Fig. 5. A facilitation model: salient themes for outdoor learning from research and practice. outdoor education business located his journal in the top drawer of his office desk. Another is now an emergency ward physician, a highstress position. When quizzed about the impact of the course on her occupation, she replied that she had especially learned "teamwork, communication and listening skills ... all integral components in the emergency ward when undergoing high risk surgery or lifethreatening procedures." When prodded during our one-on-one interview "do you still have your log book?" she pulled the journal from her bag and handed it over to the table in almost pristine condition.

The course was a catalyst for developing an adventurous spirit which continued well into adulthood. Participants also spoke of the enduring allure of wild spaces and the constant "pull" which propels them to seek recreational opportunities in nature. One declared

It didn't end with wilderness, that was the beginning ... It led to more. I did the Everest base camp trek for my 40th because of a film we had watched in wilderness class. It was inspiration, ... I was going to go there, and I did.

Whilst another mentioned

At the time, it provided a positive moment to schooling, a class I looked forward to attending compared to many others. In hindsight, it played a significant contribution to the establishment of a deep relationship I continue to have with the natural world.

\section{Discussion-Grounding the Practice}

In the words of the renowned philosopher Henry David Thoreau, "We need the tonic of wildness" (Gray, 2016, p. 3). Children's disconnect with nature has become a pressing concern for parents, educators, health professionals, and environmentalists (Anggard,
2010; Dowdell, Gray, \&t Malone, 2011; Gray, 1997, 2001, 2018b; Gray \&t Birrell, 2015; Kahn \&t Kellert, 2002; Louv, 2008, 2011; Orr, 1992, 2004; Thomas \& Thompson, 2004). This begs the question: Are our young suffering from what is commonly referred to by Louv (2011) as Vitamin N deficiency? Nature immersion has a profound impact on well-being, creativity, brain function, and mood states and is now corroborated by mounting research in this area (Selhub $\mathrm{Ct}$ Logan, 2012). Unbridled autonomy in the outdoors can also be liberating for students. Being encouraged to make choices, decisions, build confidence and mastery, also help develop a sense of purpose and meaning (Phenice \&t Griffore, 2003). Problem-solving skills, interpersonal relationships, teamwork, self-discipline, and executive functioning skills are also acquired (Henley, 2010).

Outdoor Learning is a potent vehicle for student growth and development (Hattie et al., 1997). The natural environment offers a fertile platform for transformative growth and behavior change (Dickson et al., 2008). Over time, we have learned to position and justify our work by returning to the epistemological underpinnings evidenced in nature-based practices. The underlying goal of education should be to develop the three Rs: Resilience, Reflection, and Relationship, and we believe that adopting these pedagogical practices will foster a richer educational experience for both teacher and student (Gray, 2018b). Built from our key findings, Figure 5 provides a model of facilitation to share with practitioners and scholars wanting to progress the profession further.

\section{Resilience}

Our message is clear and simple, "Get out of the way and let nature be the teacher” (Gray, Tracey, Truong, \& Ward, 2017). Allow children to take risks, nurture an adventurous spirit, and include embodied 


\section{GRAY AND PIGOTT}

experiences involving the senses and emotions. A precursor to developing resilience is one's ability to learn self-regulation, executive function, and self-control. Give permission for serendipity and synchronicity to play a crucial role in the sequencing and delivery of lessons. Discovery or problem-based learning is more important than being spoon-fed. Letting go of controlling the educational outcomes in Outdoor Learning may be a difficult concept to grasp, but time and time again, we have found students respond more enthusiastically to accidental learning, also known as the "teachable moment," as opposed to overly prescriptive, sanitized, or over-planned learning.

Terry Gaechter, an outdoor and tertiary educator, describes,

this mysterious aspect of the role of nature as backdrop: the rich soup in which all of these relationships with self and others are being worked out. It's important. It's almost like at the level it wasn't being brought explicitly into any of the learning, yet it was profound, it was powerful, it was long lasting, and these are complex questions for a young person (as cited in Blades, 2018, p. 85).

Unfettered and unregulated time in nature improves creativity. Research suggests even being around green space is enough to enhance learning such as deep and open processing, intrinsic interest, and mastery-approach motivation (Lichtenfeld, Elliot, Maier, \& Pekrun, 2012). The path less traveled is arguably taken by fewer people because it produces discomfort and promises unpredictability. Although uncertainty can be daunting, overcoming these challenges can lead to positive self-growth (Overholt \& Ewert, 2015). Risktaking, problem-solving, and inner mastery emerge as a by-product of engaging with outdoor environments. Being in nature and exposed to the elements is largely unscripted; we learn to dig deep and develop executive functioning skills.

We do not mean to imply that outdoor educators should place students in precarious situations in order to teach resilience. Research suggests that there is a resilience "sweet spot" where adversity and the means to overcome it, with social support along the way, create conditions that foster successful personal developments (Hayhurst, Hunter, Kafka, \& Boyes, 2015). Cocooned within a safety net of an indoor classroom, students predominantly retain the role of passive and unengaged learners. Interestingly, none recalled the content of lessons conducted within the four walls of the classroom for the Wilderness Studies subject. Inarguably, the sterile indoor environment does little to buttress indelible learning nor provide experiences that trigger recollection of important life lessons.

Three decades after the program, students vividly recollected embodied and visceral experiences which evoked a kaleidoscope of emotions-the highs and the lows, such as the natural aesthetic beauty or the hyperthermia and incessant rain. The physical and emotional hardships were not viewed as moments of suffering but, more importantly, as crucial transformational learning experiences. The salient message for educators is this: Lasting memories occur outside in the real world when all senses are enlivened, when emotions are engaged, and when the stakes for action and decisionmaking are real.

\section{Reflection}

The discourse on the role of well-being exercises, meditative moments, and self-knowledge in education is well-established internationally and has been incorporated into school curriculum frameworks and contemporary pedagogies (Baker, Green, \& Falecki, 2017). Positive psychological concepts such as resilience, flourishing, thriving, grit, and growth-mindset (Duckworth, 2017; Dweck, 2006; Seligman, 2011) are commonly heard by the authors in both classrooms and staff rooms. As neuroscience investigates the oncemysterious inner workings of the brain, the role of the mind and affect in learning is being clarified with clear links established between students' abilities to use positive psychology reflective techniques and academic achievement (Claro, Paunesku, \& Dweck, 2016; Waters, 2011).

Mindfulness is now a mainstream concept, with many schools incorporating programs like Smiling Mind, Class Dojo, and GoNoodle into the school day to provide moments of transition (Fraser, 2012) and to mitigate attention fatigue (Kaplan, 1995). Hayes and Ciarrochi (2015) offer a model for schools that explicitly teaches adolescents mindful practices to help them thrive-be a discoverer, noticer, and adviser. In our fast-paced lifestyles, we need to embrace slow pedagogies now more than ever before (Birrell, 2018). Offering introspective solo time in "sit spots" found in natural settings will not only heighten nature attunement but also act as a balm to help relax children with behavioral issues.

Journaling provided an opportunity for students to record their "noticings," their emotional responses to the stimulation of the outdoor environment and its challenges or inspirations. In addition, privately offering themselves written advice and recording their personal wisdoms for future reference concretized their learning. Herzog, Black, Fountaine, and Knotts (1997, as cited in Kaplan \& Berman, 2010, p. 54) report that participants consider natural environments as being more likely to encourage reflection than other environments.

Logbooks were a tangible and necessary anchor for their outdoor experience; nearly 50\% of students still had their journals kept in 
LASTING LESSONS IN OUTDOOR LEARNING

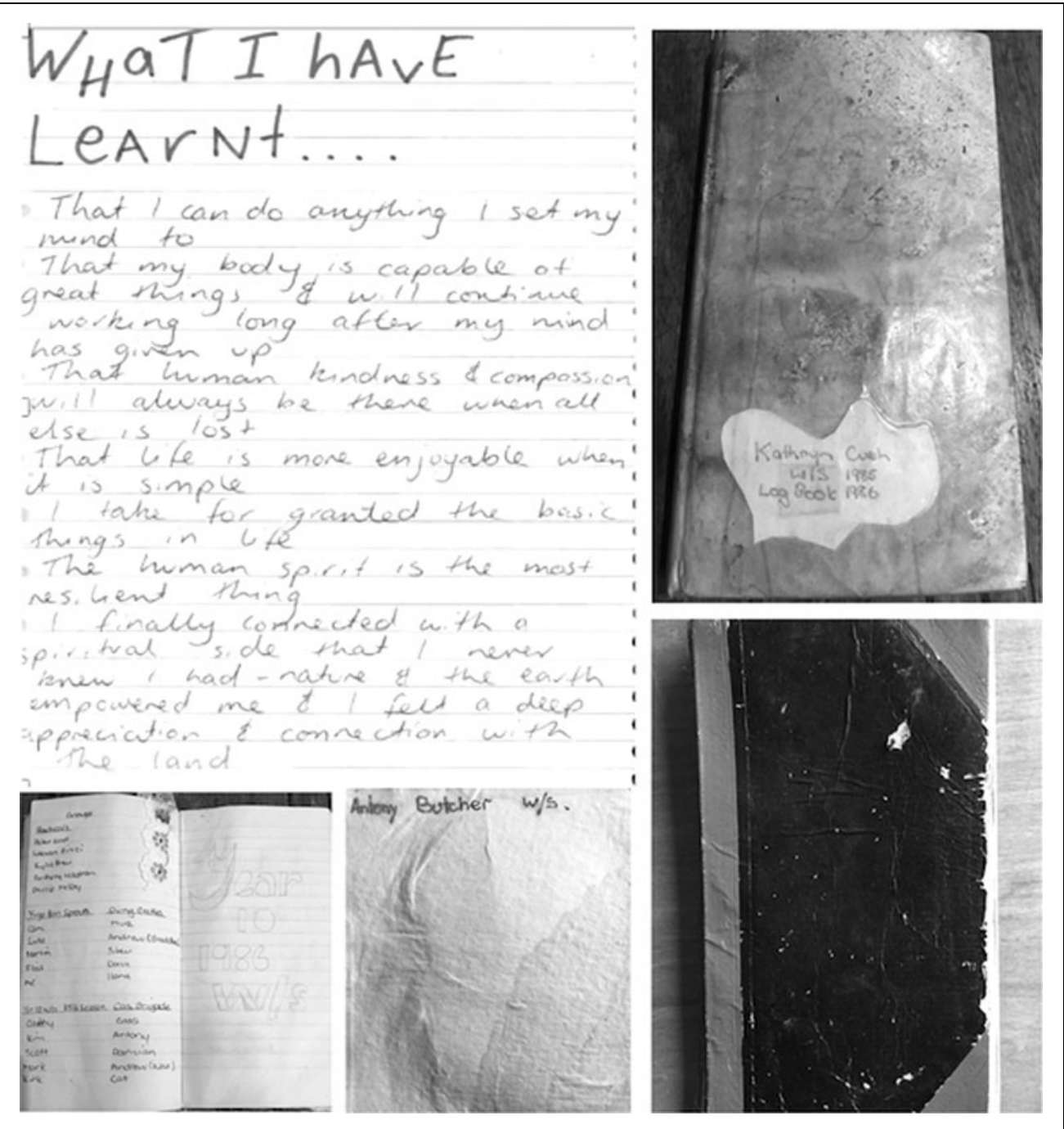

Fig. 6. Examples of logbooks/journals from 1985-1986. (Photo credit: Tonia Gray) thoughts, sharing of stories and evoking memories. In short, we are capable of thinking through our hands (Blades, 2018; Gray, 2017).

Hard copies of photographs are a "must have" artifact for all facilitators. Endless digitized images fail to have the same impact as an image that is printed and observed. The floodgate of memories filter back and are firmly anchored in the observed image. Using tactile and visceral methods for recollection, such as holding the photo and being transported back to a younger self, unlock our long-term memories (Gray, 2017).

Weaving introspective or contemplative components into expeditions during the 1980s was considered "eccentric" or "outlandish" (Birrell, 2018; Gray, 2017, 2018). Now, 30 years later, extant research supports our then-intuitive understanding that sitting quietly in nature and handwriting in journals has distinctive pedagogical advantages.

Stories are how we think and make meaning of personal experience (Berger, 1997; Labov \& Waletzky, 1997). The brain interprets the external world in a mixture of emotion, sensory input, and connections to previous experiences. It encodes these interpretations in cognitive maps or narratives, which become stronger the more often these neural pathways

special drawers or sacred spaces in their homes 30 years after being in Wilderness Studies despite multiple moves and other disruptions to their lives (see Fig. 6).

From these unambiguous observations, we posit journaling is crucial to embed long-term educational outcomes. Interestingly, handwriting is championed by both Ingold (2013) and Pallasmaa (2009) as a conduit to bring the writer into greater sympathy with the observed. Stimulating eye-hand-mind fusion through dexterous activity, such as handwriting or indigenous basket-weaving, engages are revisited (Gray \&t Stuart, 2015). Humans seem to have developed a survival mechanism of the brain, processing imagined experiences in the same way as real ones. That is, we do not need to have physically experienced something but can have anticipated or imagined it and still feel an emotion or have a behavioral response (Mobbs, Hagan, Dalgleish, Silston, \& Prevost, 2015).

Ancient cultures have used aural histories and storytelling for centuries as a crucial ingredient in teaching their young people (Wheaton, 2000, as cited in Yunkaporta \&t Kirby, 2011). Myths, 


\section{GRAY AND PIGOTT}

legends, parables or dreaming stories abound with cautionary tales to guide decision-making, teach social values, or broaden listeners' frames of reference. Thomas, Taylor, and Gray (2018) examine Aboriginal teaching traditions of sharing stories at specific locations, saying, "each rock is a story and when you hear the story, you have a responsibility to the story ... you must retell the story and pass on its essence" (p. 153). Including storytelling as a pedagogical tool in Outdoor Learning offers adolescents the opportunity to deepen their understanding of themselves, others, and the environment (Gray $\mathrm{Ct}$ Stuart, 2015; Thomas et al., 2018).

\section{Relationship}

All former students identified interpersonal skills that were enhanced from group interactions during expeditions. In particular, the benefits of teamwork and collaboration were evidenced in real-world applications. Outdoor Learning developed participants' relational and communication skills whilst also generating a feeling of success that arose from working together while engaging with the natural landscape and its inherent challenges. The friendships that were galvanized during Wilderness Studies were life-affirming, and many still remain closely associated into their adult life (Gray, 2017).

Interestingly, some now have their own adolescent children currently undertaking Wilderness Studies at the same school. Their memories of the subject were so positive and tangible, they had encouraged their children to undertake the same experience. The intergenerational transmission of environmental stewardship from parent to child provided opportunities for explicit Outdoor Learning experiences to continue toward a positive environmental ethic (Grønhøj \& Thøgersen, 2009). In addition, some had chosen careers in Outdoor Learning or related fields, so in their own lifetimes they could be instrumental in enacting environmental stewardship.

Australian adolescents are growing up in an ancient landscape with a rich indigenous history and present. Aboriginal Australians speak of connection to Country as a fundamental aspect of mental, physical, and spiritual well-being (McKnight, 2015). Learning from, with, and through the land has been ongoing in Aboriginal culture for over sixty thousand years in a reciprocal exchange "between me, the site, the site and me" (Thomas et al., 2018, p. 153). Underpinning all aspects of Outdoor Learning is the need to experience this dynamic sense of connection (Birrell, 2001).

Recently, a groundswell of interest in Indigenous culture taught through Outdoor Learning has harnessed the benefits of Aboriginal wisdom to our mainstream Australian curriculum. For example, in western New South Wales, "The eight-ways of learning" is a framework of Aboriginal pedagogy that draws similar themes as those explored in Figure 5. The model recommends teaching and learning through story sharing, deconstructing and reconstructing knowledge, nonlinear experiences, links with the land, links with community, nonverbal and introspective opportunities, learning maps or visualized knowledge, and the use of symbols and image (Yunkaporta et Kirby, 2011).

\section{Conclusion: Last Year's Fruit Nourishes Us Today and Evolves to Become Next Year's Seed}

The retrospective, mixed-method study revealed a positive, sustained impact of nature immersion on adolescent participants, with many participants currently pursuing careers, recreation, and restoration in wilderness environments. The anecdotal evidence supports the argument that participants' perceptions were changed through their involvement in nature, although we have no long-term studies that focus exclusively on the lifelong impacts of Outdoor Learning. If anything, the data suggests that, at least for some groups, these experiences remain salient and highly valued many years later. But the evidence insinuates, at least to us, that these lessons may be even more enduring than we recognized when first entering the field. The findings infer that former participants are in universal agreement with proponents that Outdoor Learning can foster psychological traits such as resilience, teamwork, camaraderie, and interpersonal skills. The residual and durable significance of Wilderness Studies three decades after completion exceed even our most optimistic hopes that experiences in nature may leave lasting impressions on our students.

The long-term benefits offer encouragement for today's educators searching for tangible pathways to engage adolescents with wild spaces. The facilitation model devised in Figure 5 has been grounded in theory and reflective practice and implemented successfully in the field. By using an amalgam of contemporary research in education, positive psychology, and neuroscience, a facilitation model has been devised by the authors. These approaches have applicability for teachers working within today's "evidence-based, effect-sized" focused educational climate.

Teachers, in general, aim to offer every child a meaningful and purposeful education and mastery of self, enabling children to enter the next stage of life equipped with all they need to thrive. They are, however, under increasing pressure with competing demands to deliver a complex curriculum accountable to the standardized test (Bates, 2018; Ewing, 2018). Usually, teachers implement "tried and tested" methodologies to meet these demands with great success. At times, however, an opportunity will arise, or an intuitive voice will whisper to offer a student something a little unusual, something a 


\section{LASTING LESSONS IN OUTDOOR LEARNING}

little risky, something a little "trailblazing." In their defense, "teachers must be trusted with responsibility for reflecting on and adjusting professional practice in the light of research evidence and their and other practitioners' knowledge and experience" (Ewing, 2018, p. 32).

Whilst writing this paper, one of the authors was working with a newly graduated teacher in her role as a Learning and Support Teacher in a low socioeconomic rural school. Having observed the increasing disengagement of the Year 1 class after an hour of focused literacy instruction, I suggested heading outside for a walk in the permaculture garden nearby the classroom to "give our brains a break." Her new colleague's bemused response was, "Can we do that?" "Of course, we can" was my immediate reply. And more specifically, we can now justify our educational decision to anyone who asks, as these actions are based on sound empirical research.

We hope this waymark study offers encouragement to today's practitioners to follow a creative edge, to build on established wisdom and be innovative. For, even though it may take decades for research to validate today's "knowing," the sustained positive impact on the children in your classroom may be assisting them to thrive in the long-term. Be brave and lead with courage and conviction.

\section{Acknowledgments}

We wish to thank the students in this 30-year retrospective study for gladly giving their time and sharing their invaluable stories.

\section{REFERENCES}

Anggard, E. (2010). Making use of "nature" in an outdoor preschool: Classroom, home and fairyland. Children, Youth and Environments, 20, 4-25.

Baker, L., Green, S., \& Falecki, D. (2017). Positive early childhood education: Expanding the reach of positive psychology into early childhood. European Journal of Applied Positive Psychology, 1. Retrieved from http://www.national wellbeingservice.org/volumes/volume-1-2017/volume-1-article-8

Barton, J., Bragg, R., Pretty, J., Roberts, J., \& Wood, C. (2016). The wilderness expedition: An effective life course intervention to improve young people's well being and connectedness to nature. Journal of Experiential Education, 39, $59-72$.

Bates, K. (2018). Bringing the inside out and the outside in: Place-based learning rendering classroom walls invisible. In T. Gray \& D. Mitten (Eds.), The Palgrave international handbook of women and outdoor learning (pp. 731-751). London, UK: Palgrave Macmillan.

Berger, A. A. (1997). Narratives in popular culture, media and everyday life (2nd ed.). Thousand Oaks, CA: Sage Publications.

Biddulph, S. (2013). Raising girls. London, UK: Harper Thorson.

Birrell, C. (2001). A deepening relationship with place. Australian Journal of Outdoor Education, 6, 25-31.
Birrell, C. (2018). Eyes wide shut: A history of blindness towards the feminine in outdoor education in Australia. In T. Gray \& D. Mitten (Eds.), The Palgrave international handbook of women and outdoor learning (pp. 473-488). London, UK: Palgrave Macmillan.

Blades, G. (2018). Elder women speak of outdoor learning and experience. In T. Gray \& D. Mitten (Eds.), The Palgrave international handbook of women and outdoor learning (pp. 75-94). London, UK: Palgrave Macmillan.

Buhrmester, D. (1990). Intimacy of friendship, interpersonal competence and adjustment during preadolescence and adolescence. Child Development, 61, 1101-1111.

Bukowski, W. M., Hoza, B., \&t Boivin, M. (1993). Popularity, friendship, and emotional adjustment during early adolescence. New Directions for Child and Adolescent Development, 60, 23-37.

Chawla, L. (2007). Childhood experiences associated with care for the natural world: A theoretical framework for empirical results. Children, Youth and Environments, 17, 144-170.

Claro, S., Paunesku, D., \& Dweck, C. S. (2016). Growth mindset tempers the effects of poverty on academic achievement. Proceedings of the National Academy of Sciences, 113, 8664-8668.

Dickson, T., Gray, T., \& Mann, K. (2008). Australian outdoor adventure activity benefits: A catalogue. Retrieved from https://outdoorsvictoria.org.au/resources/ australian-outdoor-adventure-activity-benefits-catalogue/.

Dowdell, K., Gray, T. \& Malone, K. (2011). Nature and its Influence on Children's Outdoor Play. Journal of Outdoor and Environmental Education, 15, 24-35. https://link.springer.com/article/10.1007/BF03400925.

Duckworth, A. (2017). Grit: The power of passion and perseverance. London, UK: Vermilion.

Dweck, C. S. (2006). Mindset: The new psychology of success. New York, NY: Random House

Ewing, R. (2018). Exploding some of the myths about learning to read: A review of research on the role of phonics. Surry Hills, Australia: NSW Teachers Federation. Retrieved from https://www.alea.edu.au/documents/item/1869

Fraser, A. (2012). The third space: Using life's little transitions to find balance and happiness. North Sydney, Australia: Random House.

Gray, T. (1997). The impact of an extended stay outdoor education school program upon adolescent participants (Doctoral dissertation). Wollongong, Australia: University of Wollongong. Retrieved from http://ro.uow.edu.au/theses/1799

Gray, T. (2001). Ruminating, reflecting and redefining: Why was I attracted to outdoor education? Australian Journal of Outdoor Education, 6, 2-4.

Gray, T. (2016). Foreword: Benefits of human-nature relationships. Planet Ark. Retrieved from http://treeday.planetark.org/research

Gray, T. (2017). A 30-year retrospective study of the impact of outdoor education upon adolescent participants: Salient lessons from the field. Pathways: The Ontario Outdoor Education Journal, 29, Spring, 4-15.

Gray, T. (2018a). Thirty years on and has gendered landscape changed in outdoor learning? In T. Gray \& D. Mitten (Eds.), The Palgrave international handbook of women and outdoor learning (pp. 35-54). London, UK: Palgrave Macmillan.

Gray, T. (2018b). Outdoor learning: Not new, just newly important. Curriculum Perspectives, 38, 145-149.

Gray, T., \& Birrell, C. (2015). 'Touched by the Earth': a place-based outdoor learning programme incorporating the Arts. Journal of Adventure Education and Outdoor Learning, 15, 330-349. Retrieved from http://dx.doi.org/10.1080/ 14729679.2015 .1035293$. 


\section{GRAY AND PIGOTT}

Gray, T., \& Perusco, D. (1993). Footprints in the sand-Reflecting upon the value of outdoor education in the school curriculum. Australian Council for Health, Physical Education and Recreation. National Journal, 40, 17-21.

Gray, T., \& Stuart, K. (2015). The power of storytelling in adventure education. In C. Norton, C. Carpenter, \& A. Pryor (Eds.). Adventure therapy around the globe: International perspectives and diverse approaches (pp. 393-407). Champagne, IL: Common Ground Publishing.

Gray, T., Tracey, D., Truong, S., \& Ward, K. (2017). Fostering the wellbeing of students with challenging behaviour and/or emotional needs through acceptance commitment therapy and outdoor learning: Research report. Sydney, Australia: Centre for Educational Research, School of Education, Western Sydney University.

Grønhøj, A., \& Thøgersen, J. (2009). Like father, like son? Intergenerational transmission of values, attitudes, and behaviours in the environmental domain. Journal of Environmental Psychology, 29, 414-421.

Hattie, J., Marsh, H. W., Neill, J. T., \& Richards, G. E. (1997). Adventure education and Outward Bound: Out-of-class experiences that make a lasting difference. Review of Educational Research, 67, 43-87.

Hayes, L., \& Ciarrochi, J. (2015). The thriving adolescent: Using acceptance and commitment therapy and positive psychology to help teens manage emotions, achieve goals, and build connections. Oakland, CA: Context Press.

Hayhurst, J., Hunter, J., Kafka, S., \& Boyes, M. (2015). Enhancing resilience in youth through a 10-day developmental voyage. Journal of Adventure Education and Outdoor Learning, 15, 40-52.

Henley, J. (2010, August 16). Why our children need to get outside and engage with nature. The Guardian. Retrieved from https://www.theguardian.com/ lifeandstyle/2010/aug/16/childre-nature-outside-play-health

Hoogerheide, V., \& Paas, F. (2012). Remembered utility of unpleasant and pleasant learning experiences: Is all well that ends well? Applied Cognitive Psychology, 26, 887-894.

Ingold, T. (2013). Making: Anthropology, archaeology, art and architecture. Oxon, UK: Routledge.

Kahn, P. H., \& Kellert, S. R. (2002). Children and nature: Psychological, sociocultural and evolutionary investigations. Cambridge, MA: MIT Press.

Kaplan, S. (1995). The restorative benefits of nature: Towards an integrative framework. Journal of Environmental Psychology, 15, 169-182.

Kaplan, S., \& Berman, M. (2010). Direct attention as a common resources for executive function and self-regulation. Perspectives on Psychological Science, 5, 43-57.

Kolb, D. (1984). Experiential learning: Experience as the source of learning and development. Englewood Cliffs, NJ: Prentice-Hall.

Labov, W., \& Waletzky, J. (1997). Narrative analysis: Oral versions of personal experience. Journal of Narrative and Life History, 7, 3-38.

Lichtenfeld, S., Elliot, A. J., Maier, M. A., \& Pekrun, R. (2012). Fertile green: Green facilitates creative performance. Personality and Social Psychology Bulletin, 38, 784-797.

Liddicoat, K. R., \& Krasny, M. E. (2014). Memories as useful outcomes of residential outdoor environmental education. The Journal of Environmental Education, 45, 178-193.

Louv, R. (2008). Last child in the woods. Chapel Hill, NC: Algonquin Books of Chapel Hill. Louv, R. (2011). The nature principle: Human restoration and the end of naturedeficit disorder. Chapel Hill, NC: Algonquin Books of Chapel Hill.

McKnight, A. (2015) Mingadhuga Mingayung: Respecting country through Mother Mountain's stories to share her cultural voice in Western academic structures. Educational Philosophy and Theory, 47, 276-290.
Mezirow, J. (2000). Learning as transformation: Critical perspectives on a theory in progress. San Francisco, CA: Jossey-Bass.

Mobbs, D., Hagan, C. C., Dalgleish, T., Silston, B., \&t Prevost, C. (2015). The ecology of human fear: Survival optimization and the nervous system. Frontiers in Neuroscience, 9, doi:10.3389/fnins.2015.00055

Orr, D. W. (1992). Ecological literacy: Education and the transition to a postmodern world. New York, NY: SUNY Press.

Orr, D. W. (2004). Earth in mind: On education, environment, and the human prospect. Washington, DC: Island Press.

Overholt, J., \& Ewert, A. (2015). Gender matters: Exploring the process of developing resilience through outdoor adventure. The Journal of Experiential Education, $38,41-55$.

Pallasmaa, J. (2009). The thinking hand: Existential and embodied wisdom in architecture. Chichester, UK: John Wiley and Sons.

Phenice, L., \& Griffore, R. (2003). Young Children and the Natural World. Contemporary Issues in Early Childhood, 4, 167-178.

Ryan, D., \& Gray, T. (1993). Integrating outdoor education into the school curriculum-A case study. International Council for Health, Physical Education and Recreation, 29, 6-13.

Selhub, E., \& Logan, A. (2012). Your brain on nature: The science of nature's influence on your health, happiness and vitality. Somerset, UK: Wiley.

Seligman, M. (2011). Flourish. New York, NY: Free Press.

Sibthorp, J., Paisley, K., Furman, N., \& Gookin, J. (2008). Long-term impacts attributed to participation in wilderness education: Preliminary findings from NOLS. In Ninth Biennial Research Symposium (p. 115).

Thomas, G., \& Thompson, G. (2004). A Child's Place: Why Environment Matters to Children. London, Green Alliance / Demos Report.

Thomas, L., Taylor, N., \& Gray, T. (2018). Building relationship on and with Mother Mountain: Women incorporating Indigenous knowledge into outdoor learning, In T. Gray \& D. Mitten (Eds.), The Palgrave international handbook of women and outdoor learning (pp. 147-168). London, UK: Palgrave Macmillan.

Waters, L. (2011). A review of school-based positive psychology interventions. The Australian Educational and Developmental Psychologist, 28, 75-90.

Yunkaporta, T., \& Kirby, M. (2011). Yarning up Aboriginal pedagogies: A dialogue about eight Aboriginal ways of learning. In N. Purdie, G. Milgate, \& H. R. Bell (Eds.), Two way teaching and learning: Toward culturally reflective and relevant education (pp. 205-213). Camberwell, Australia: ACER Press.

Address correspondence to:

Tonia Gray

Western Sydney University School of Education Locked Bag 1797 Penrith Penrith South, NSW 2751

Australia

E-mail: t.gray@westernsydney.edu.au

Received: May 7, 2018 Accepted: August 6, 2018 